\title{
Refluxing Megaureter
}

National Cancer Institute

\section{Source}

National Cancer Institute. Refluxing Megaureter. NCI Thesaurus. Code C123192.

A meg aureter that demonstrates retrog rade urine flow without ureteral obstruction. 